\title{
Türkiye Şartlarında Ilık Karışım Asfalt Uygulamasının Ekonomik ve Çevresel Değerlendirmesi
}

\author{
Kemal KARAKUZU ${ }^{1 *}$ (D), Halit ÖZEN² \\ ${ }^{1}$ İnşaat Mühendisliği, Bursa Uludağ Üniversitesi, Bursa, 16059, Türkiye \\ ${ }^{2}$ İnşaat Mühendisliği, Yıldız Teknik Üniversitesi, İstanbul, 34220, Türkiye
}

Geliș / Received: 24/09/2019, Kabul / Accepted: 23/04/2020

\begin{abstract}
$\ddot{O} z$
Ilık Karışım Asfalt (IKA) teknolojisi, Bitümlü Sıcak Karışımlara (BSK) göre önemli derecede enerji tasarrufu ve çevre katkısı sunmaktadır. IKA üretiminde viskozitenin düşürülerek işlenebilirliğin artması sayesinde $100^{\circ} \mathrm{C}-140^{\circ} \mathrm{C}$ arasında üretim yapılabilirken, BSK'da ise $150^{\circ} \mathrm{C}-190^{\circ} \mathrm{C}$ arasında üretim yapılması mümkün olmaktadır. Ayrıca IKA kullanımı; üstyapının performans ömrünün uzaması, gaz emisyonunun azalması, işçi sağlığına katkısı, inşaat sezonunun uzaması, daha uzun mesafelere taşıma imkânı vermesi gibi önemli avantajları da sağlamaktadır. IKA teknolojisi, Avrupa ve Amerika'da yaygın olarak kullanılmakta olup ülkemiz için henüz yeni bir teknolojidir. Bu çalışmada literatür bilgisine yer verildikten sonra BSK'nın çeşitli yıllardaki maliyeti hesaplanarak farklı IKA üretim yöntemleriyle karşılaştırılmış, ayrıca IKA kullanımının çevreye etkisi değerlendirilmiştir. Bunun yanında, bitüm maliyetinin toplam asfalt karışımı maliyetine etkisi incelenerek BSK veya IKA seçimi için en uygun bitüm maliyeti/toplam maliyet oranı elde edilmiştir. Bu bağlamda daha önceki çalışmalarda değinilmemiş olan BSK ve IKA'nın çevresel ve ekonomik açıdan karşılaştırılması yapılarak literatüre katkı sağlanması hedeflenmiştir. Sonuç olarak IKA kullanımının en büyük katkısının çevresel faydası olduğu göz önünde tutulmalıdır. IKA'nın kullanılmasına karar verilirken üretim maliyetinin yanında çevre dostu bir karışım olan IKA'nın çevresel faydalarının da dikkate alınmasının gerekliliği ortaya çıkmaktadır.
\end{abstract}

Anahtar Kelimeler: Asfalt kaplama, bitümlü sıcak karışım, BSK, 1lık karışım asfalt, IKA

Economic and Environmental Assessment of Warm Mix Asphalt Application in Turkey Condition

\begin{abstract}
Warm Mix Asphalt (WMA) technology gives significant energy saving and environmental contributions according to the Hot Mix Asphalt (HMA). Thanks to increased of workability by reduced viscosity in the production of WMA, asphalt mixture can be mixed at lower temperatures changing from $100^{\circ} \mathrm{C}-140^{\circ} \mathrm{C}$ comparing with $\mathrm{HMA}\left(150^{\circ} \mathrm{C}-190^{\circ} \mathrm{C}\right)$ without compromising the performance properties. WMA technology has many important benefits such as prolonging the performance life of the pavement, reduction of greenhouse gas emission, contribution to worker health, longer fabrication period and transport over a longer distance. WMA technology is a very new technology for Turkey but it is very popular in especially the USA and among Europe countries. The cost and benefit analysis and comparison of HMA with WMA through several years also presented. Morover, the environmental impact of WMA technology is discussed. In addition, the effect of bitumen cost which is the most important factor obtaining the total asphalt mixture cost is investigated and the most appropriate bitumen/total cost ratio is determined for HMA or WMA selection. The aim of this study is to provide a contribution to the literature by comparing the environmental and economic aspects of HMA and WMA which are not mentioned in previous researches. Consequently, it should be kept in mind that the greatest contribution of using WMA is its environmental benefit. When deciding, it is necessary to take into consideration the environmental benefits of WMA, which is an environmentally friendly mixture.
\end{abstract}

Keywords: Asphalt pavement, hot mix asphalt, HMA, warm mix asphalt, WMA 


\section{Giriş}

Ülkemizde son yıllarda ulaştırma alanında yapılan yatırımların artmasıyla beraber Bitümlü Sıcak Karışımların (BSK) tüketimi de artmıştır. Yolcu taşımacılığının \%90'1 ve yük taşımacılığının \%78'inin karayolları ile yapıldığı düşünüldüğünde BSK'nın ulaştırma işletmesi ve planlaması konusunda ne kadar önemli olduğu ortaya çıkmaktadır (Köroğlu vd, 2015). Karayollarının yapım ve bakım maliyetlerinin yüksek olmasının yanında dünya genelinde enerji ihtiyacı ciddi problem oluşturmaktadır. Ayrıca küresel 1sınmayla birlikte çevre bilincinin artmasıyla araştırmacılar, çevre dostu ve ekonomik yeni teknolojiler geliştirmişlerdir. Ekonomik ve çevreye duyarlı olması açısından Ilık Karışım Asfalt (IKA), dünya genelinde yeni teknoloji olarak kabul görmeye başlamıştır (Randon et al., 2015).

BSK, $\quad 150-190^{\circ} \mathrm{C}$ arasındaki bir sicaklıkta üretilirken, IKA'nın üretilmesi daha düşük sicaklıklarda (tipik olarak $100-140^{\circ} \mathrm{C}$ arasında) gerçekleştirilir (Croteau and Tessier, 2008). Tablo 1'de Türkiye'de y1llara göre üretilen BSK miktarları verilmiştir (ASMÜD, 2019).

Tablo 1. Türkiye'de yıllara göre üretilen BSK miktarları (ASMÜD, 2019)

\begin{tabular}{lllll}
\hline Yıl & $\begin{array}{l}\text { BSK } \\
(\text { milyon } \\
\text { ton) }\end{array}$ & $\begin{array}{l}\text { Sathi } \\
\text { Kaplama } \\
\left(\mathbf{k m}^{2}\right)\end{array}$ & $\begin{array}{l}\text { Soğuk } \\
\text { Kaplama } \\
(\mathbf{x 1 0 0 0} \\
\text { ton) }\end{array}$ & $\begin{array}{l}\text { Bitüm } \\
\text { Tüketimi } \\
(\mathbf{x 1 0 0 0} \\
\text { ton) }\end{array}$ \\
\hline $\mathbf{2 0 1 2}$ & 38.30 & 294.90 & 1.82 & 2.81 \\
$\mathbf{2 0 1 3}$ & 46.20 & 216.30 & 1.05 & 2.82 \\
$\mathbf{2 0 1 4}$ & 30.90 & 203.80 & 0.94 & 2.39 \\
$\mathbf{2 0 1 5}$ & 37.90 & 269.20 & 0.78 & 2.73 \\
$\mathbf{2 0 1 6}$ & 40.40 & 306.40 & 0.54 & 2.93 \\
$\mathbf{2 0 1 7}$ & 46.90 & 268.40 & 1.05 & 3.62 \\
\hline
\end{tabular}

Gerekli düzeltmeler, diğer paragraflarla birleştirilerek aşağıdaki gibi yapıldı.

"Yapılan çalışmalarla IKA teknolojisinin düşük sicaklıklarda üretilebilmesi sayesinde enerji tüketimini $\% 30$ oranında ve gaz emisyonunu \%30-\%50 arasında azaltabileceği kanıtlanmıştır (Arega and Bhasin, 2012). Bunun yanında IKA'nın performans özellikleri düşük sıcaklıklardaki üretim şartlarından ciddi şekilde etkilenmez (D'Angelo et. al, 2008). Bu durum hem üretimde avantaj sağlar (D'Angelo et. al, 2008; Arega and Bhasin, 2012) hem de düşük sicakl1kta uygulama imkanı sunar (Arega and Bhasin, 2012; Chowdhury and Button, 2008). Bu nedenle daha az termal segregasyon ve toz oluşur. $\mathrm{Bu}$ durum çalışanlar için daha sağlıklı çalışma şartlarının oluşmasını sağlar. Düşük sıcaklıklarda uygulanabilmesi sayesinde, daha uzak mesafelere taşınabilme imkanı verir. Bu sayede geniş pazar imkânı sunar. Böylece daha önce asfalt uygulamasında başarılı olunamayan yerlerde de uygulanabilir. Ek olarak BSK'ya göre sezon dışında da asfalt karışımlarının serilmesi mümkündür. Ayrıca, üretim ve serme sırasında daha az yaşlanmaya maruz kaldığından daha uzun servis ömrü elde edilir (Arega and Bhasin, 2012). Asfalt karışımları üretiminde, sıcaklık artışıyla birlikte bitümün viskozitesi düşer ve bu sayede agrega bitümle kaplanır. IKA üretiminde ise, çeşitli yöntemler kullanılarak BSK'ya göre daha düşük sıcaklıklarda asfalt karışımı elde edilir (Kristjánsdóttir, 2007). “

IKA teknolojisi, uygulama ve planlama aşamasında bazı hususlara dikkat edilmemesi durumunda BSK'ya karşı avantajını kaybedebilir. IKA ile yakıt tüketim miktarlarının düşmesi ilk üretim miktarını azaltması açısından önemli avantaj sağlamasına rağmen uzun vadede toplam ömür maliyetini düşürüyorsa, bu konuda ömürmaliyet analizinin iyi yapılması gerekmektedir (Kristjánsdóttir, 2007). 
Asfalt kaplamalar konusunda önemli bir performans kriteri olan özelliklerden birisi de neme karşı hassasiyettir. Agregaların uygun şekilde 1sitılmadan kullanıldığı durumlarda tamamen kurumayan agrega ile bağlayıcılar arasında yeterli kohezyon oluşamayacağından soyulma meydana gelebilmektedir (Hurley and Prowel, 2006). Agrega ve bitüm arasındaki zayıf kenetlenme, hava boşluğu ve nem gibi olumsuz etkenler nedeniyle IKA, mikro ölçekli çatlaklara karşı narin davranış sergiler. IKA'nın bu özelliği ise özellikle düşük sıcaklılar altında trafik etkisi veya termal yorulma altında servis ömrünü etkileyen en önemli parametrelerden birisidir. $\mathrm{Bu}$ nedenle, asfalt karışımlarında çatlak gelişimi konusu, asfalt kaplama tasarımı için büyük önem arz etmektedir (Maurer et al., 1989; Mansourian et al., 2016).

BSK üretiminde homojen bir karışım elde edebilmek için bitümün viskozitesi düşürülerek akıcı bir kıvam elde edilir. Bunun için gereken yüksek sıcaklıklar, atmosfere ciddi miktarda emisyon gazı salımına neden olmaktadır. IKA teknolojisinin BSK'ya göre daha düşük sıcaklıklarda üretime imkan vermesi sayesinde üretimde ortaya çıkan emisyon gazlarında düşüş gözlemlenir. $\mathrm{Bu}$ emisyon gazları çok çeşitlidir. Söz konusu gazlardan en önemli ve zararlı olanlar1 ise nitrojen oksit $\left(\mathrm{NO}_{\mathrm{x}}\right)$, karbondioksit $\left(\mathrm{CO}_{2}\right)$, karbonmonoksit $(\mathrm{CO})$, hidrokarbon $(\mathrm{HC})$ ve toz parçacıklarıdır (Hassan, 2010; Bueche, 2009). Sanayi devrimiyle birlikte makine kullanımının artışı, $\mathrm{CO}_{2}$ salımında \%30, $\mathrm{NO}_{\mathrm{x}}$ salımında ise \%15 mertebesinde artış meydana getirmiştir. Emisyon gazlarının 1sı tutma özelliğinden dolayı küresel 1sınmanın neden olduğu etkiler, özellikle son yüzyılda dünyayı telafisi mümkün olmayacak şekilde etkilemektedir. Özellikle $\mathrm{CO}_{2}$ salımındaki ciddi artıştan dolayı atmosferin 1S1 hapsetme özelliğinde $\% 60$ oranında yükselme görülmüştür (Pekin, 2006).
Hassan ve arkadaşları (2010) tarafindan yapılan bir çalışmada, köpük teknolojisi ile üretilen IKA'nın çevreye katkısı değerlendirilmiştir. Buna göre IKA, BSK'ya göre küresel 1sınmada \%3, fosil yakıt tüketiminde $\% 18$, hava kirliliğinde $\% 24.3$ ve zehirli gaz salımında \%10.5 azalma sağlamıştır.

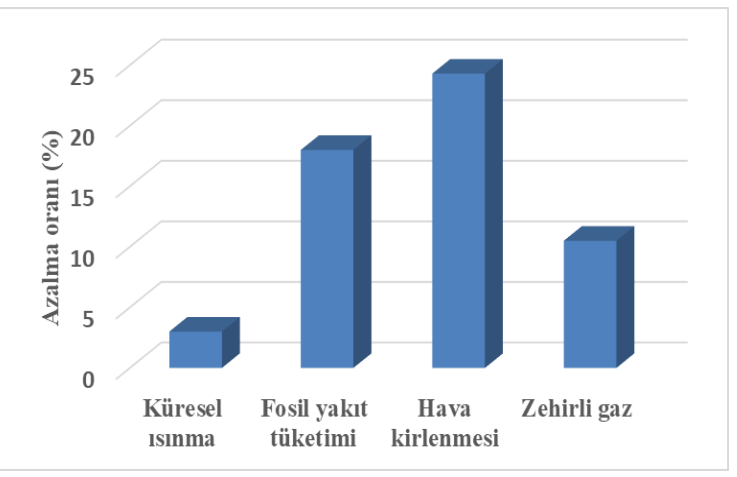

Şekil 1. IKA'nın çevreye katkısı (Hassan et al., 2010)

\section{Materyal ve metot}

\subsection{Materyal}

IKA teknolojisinin amac1, bitümün viskozitesinin düşürülerek agreganın daha düşük sıcaklıklarda bitümle istenilen şekilde kaplanmasının sağlanması ve BSK'ya eşit veya daha iyi performans elde edilmesidir (Croteau and Tessier, 2008). Bu amaçla çeşitli katkılar kullanılarak veya bitümün hacmi artırılarak viskozite düşürülebilmektedir. Literatüre göre, genellikle IKA teknolojisi üç kategoriye ayrılmıştır (Chowdhury and Button, 2008; Estakhri et al., 2010): i) Organik katkılar, ii) Kimyasal katkılar ve iii) Köpüklendirme teknolojisi.

Sicaklık, bal mumunun erime noktasının üstüne çıktığında, karışıma eklenen organik katkılar eriyerek bitümün viskozitesinin düşmesini sağlar (Rubio et al., 2012). Bu sayede karışımın işlenebilirliği artar ve agrega bitümle kaplanmış olur. 
IKA teknolojisinde kullanılan bir diğer tür de kimyasal katkılardır. Diğer IKA teknolojileriyle aynı işlem mantığına sahip olmasına rağmen bitümün performansını artıran ekstra etmenler içerir. Kullanılan kimyasal katkılar; emülsiyonlaştırma etmeni, kayganlaştırıcılar, agreganın tamamen kaplanarak karışımın işlenebilirliği ve sıkıştırılabilirliğini artırmak için kullanılan katkılar ve polimerler içerir. $\mathrm{Bu}$ katkılar sayesinde, karıştırma ve sıkıştırma işleminin uygun şekilde yapılması için gereken viskozite sağlanmadan da asfalt karışımları elde edilebilir (Rubio et al., 2012; Zaumanis, 2010). Köpüklendirme teknolojisi ise su püskürtme ve su esaslı katkı olmak üzere ikiye ayrılır. Su püskürtme yönteminde, karıştırma işlemi sırasında karışımın içine doğrudan ince su partikülleri enjekte edilir. $\mathrm{Bu}$ yöntemde su tanecikleri sıcak karışıma püskürtüldükten sonra buhara dönüşür. Böylece suyun köpüklenmesinden dolayı suyun hacminde 1.673 oranında artış meydana gelir. $\mathrm{Bu}$ hacim artışı karışımın viskozitesini düşürür ve bitümün kaplayıcılı̆̆ının artmasına yardımcı olur. Diğer köpüklendirme yönteminde ise; içeriğinde karışımın köpüklenmesini sağlayan su mineralleri (içeriğinde $\% 20$ oranında su kristali içerir) bulunan genellikle zeolit cinsinden mineraller kullanılır. Yaklaşık $100^{\circ} \mathrm{C}$ 'de su ayrılarak kontrollü bir şekilde karışımın köpüklenmesi sağlanır. Hacim artışıyla birlikte karışımın viskozitesi azalır ve 6-7 saat boyunca veya sıcaklığ $100^{\circ} \mathrm{C}$ 'nin altına düşene kadar işlenebilirliği yüksek bir karışım elde edilmiş olur (Dokandari, 2012).

\subsection{Metot}

$\mathrm{Bu}$ bölümde sıcak asfalt ve 1lık asfalt karışımlarının malzeme temini, hazırlanması ve yerinde serilmesine kadar geçen sürece ilişkin maliyetler hesaplanmıştır. Yapılan hesaplamalar Karayolları Genel Müdürlüğü'nün (KGM) yayınladığg “2012-2018 Yılı Yol, Köprü, Tünel, Bitümlü Kaplamalar, Bakım ve Trafik İşlerine Ait Birim Fiyat Listesi” (KGM, 2018) esas alınarak gerçekleştirilmiş ve elde edilen rakamların doğruluğu ilgili kurumla görüşülerek sınanmıştır. Çalışmada organik katkı, kimyasal katkı ve köpük teknolojisi sınıfından birer katkı seçilerek uygun oranlarda kullanılmış ve 3 farklı katkı malzemesinin kullanılması durumuna göre IKA maliyetlerinin her bir yıl için ayrı ayrı hesaplamaları yapılarak BSK'ya göre maliyet karşılaştırması yapılmıştır. Katkı malzemelerinin birim fiyatları ilgili temsilciliklerden temin edilmiştir. Bitümlü sıcak karışım ile 1lık asfalt karışımlarının maliyet karşılaştırmasında 1 ton bitümlü sıcak karışımın 5 cm kalınlığında TİP-1 aşınma tabakası imalatına göre malzeme temini, karıştırılması ve taşınması maliyetlerine göre yapılmıştır. IKA'ın BSK'ya göre önemli avantajlarından biri, uzak mesafelere taşınabilme imkânıdır (Arega and Bhasin, 2012). Bu avantajının değerlendirilebilmesi için farklı taşıma mesafelerine göre maliyet karşılaştırması yapılmıştır. Ekonomik karşılaştırma aşamasında IKA kullanımının sağladığı enerji tasarrufunun belirlenmesinde Tubitak ve KGM tarafindan yapılan çalışmalardan yararlanılmıştır (Köroğlu vd, 2015; TÜBİTAK MAM ve KGM, 2014).

\section{Kullanılan veriler}

Ekonomik karşılaştırma yapmak amacıyla petrol, bitüm, avro ve döviz fiyatları yıllara göre belirlenmiştir. $\mathrm{Bu}$ amaçla verilere ulaşılabilirlik faktörü göz önünde bulundurularak, 2012 y1l için 20.11.2012, 2013 y1lı için 27.12.2013, 2014 y1lı için 01.12.2014, 2015 y1lı için 23.12.2015, 2016 y1l için 14.12.2016, 2017 y1lı için 22.12.2017, 2018 yılı için 25.12.2018 tarihleri seçilmiştir. Petrol fiyatları dolara endeksli, katk1 fiyatları ise avroya endekslidir. Hesaplamalarda, TÜPRAŞ İzmit Rafinerisi çıkışlı B50/70 penetrasyonlu bitüm kullanılmıştır. 
Ayrıca asfalt karışımlarının üretim yeri olarak Karayolları Genel Müdürlüğü 14. Bölge Müdürlüğü (Bursa) seçilmiştir. Asfalt karışımlarının üretilmesinde kullanılan agreganın konkasöre ve konkasörden şantiyeye nakliye mesafesi $10 \mathrm{~km}$ olarak kabul edilmiştir. Tablo 2'de, bu tarihlerdeki petrol (tr.investing.com, 2019), bitüm (Tüpraş, 2019) dolar ve avro değerleri (MB, 2019) gösterilmiştir. Dolar ve avronun maliyet artışlarındaki etkisinin daha iyi gözlemlenebilmesi için tabloda bitüm fiyatlarının yanında petrol fiyatlarına da yer verilmiştir. Çalışma kapsamında, daha önce yapılan çeşitli laboratuvar çalışmaları esas alınarak (Kaya, 2014; Oylumluoğlu, 2012); organik katkı (O'Sullivan and Wall, 2009; Kanitpong, 2008), kimyasal katk1 (Chowdhury and Button, 2008 ve köpüklendirme teknolojisi (Estakhri et al., 2010) için ağırlıkça bitüm ve katkı oranları belirlenerek
Tablo 3'te verilmiştir. Çalışmada kullanılan bitüm ve katkı oranları Tablo 3'te gösterilmiştir. IKA'nın üretimi sırasında ortaya çıkan enerji tasarrufu tüm yıllar için sabit alınmıştır (TÜBİTAK MAM ve KGM, 2014).

\section{Bulgular ve tartışma}

\subsection{Ekonomik tartışma}

2012-2018 aras1 y1llara ait BSK ve IKA maliyetleri ayrı ayrı hesaplanmış ve sırasıyla Şekil 2, Şekil 3, Şekil 4, Şekil 5, Şekil 6, Şekil 7 ve Şekil 8'de karşılaştırmalı olarak gösterilmiştir.

2012 yılında 3 farklı katkı kullanılarak elde edilen tüm IKA karışımlarına ait maliyet karşılaştırmasına göre, BSK maliyetinin daha yüksek olduğu görülmektedir (Şekil 2).

Tablo 2. Petrol ve bitüm fiyatları ile dolar ve avronun çeşitli yıllardaki karşılıkları (tr.investing.com, 2019; Tüpraş, 2019; MB, 2019)

\begin{tabular}{llllllll}
\hline & $\mathbf{2 0 1 2}$ & $\mathbf{2 0 1 3}$ & $\mathbf{2 0 1 4}$ & $\mathbf{2 0 1 5}$ & $\mathbf{2 0 1 6}$ & $\mathbf{2 0 1 7}$ & $\mathbf{2 0 1 8}$ \\
\hline Petrol (Varil/Dolar) & 96.49 & 97.69 & 53.27 & 38.10 & 56.82 & 66.87 & 61.98 \\
Bitüm (TL/Ton) & 1100.00 & 1293.00 & 856.48 & 381.78 & 1101.91 & 1433.19 & 1704.88 \\
$\mathbf{1}$ Dolar (TL) & 1.80 & 2.15 & 2.23 & 2.92 & 3.48 & 3.81 & 5.31 \\
$\mathbf{1}$ Avro (TL) & 2.32 & 2.84 & 2.76 & 3.20 & 3.70 & 4.52 & 6.05 \\
\hline
\end{tabular}

Tablo 3. BSK ve IKA'da kullanılan bitüm ve katk1 oranı (D’Angelo et al.., 2008; Rubio et al.. , 2012; Chowdhury and Button, 2008; O’Sullivan and Wall, 2009)

\begin{tabular}{ccccc}
\hline BSK & $\begin{array}{c}\text { Organik } \\
\text { Katkı }\end{array}$ & $\begin{array}{c}\text { Kimyasal } \\
\text { Katkı }\end{array}$ & $\begin{array}{c}\text { Köpüklendirme } \\
\text { Teknolojisi }\end{array}$ \\
\hline $\begin{array}{c}\text { Bitüm } \\
(\%)\end{array}$ & 4.80 & 4.20 & 4.46 & 4.70 \\
$\begin{array}{c}\text { Katkı } \\
(\%)\end{array}$ & - & 3.00 & 2.00 & 5.00 \\
\hline
\end{tabular}




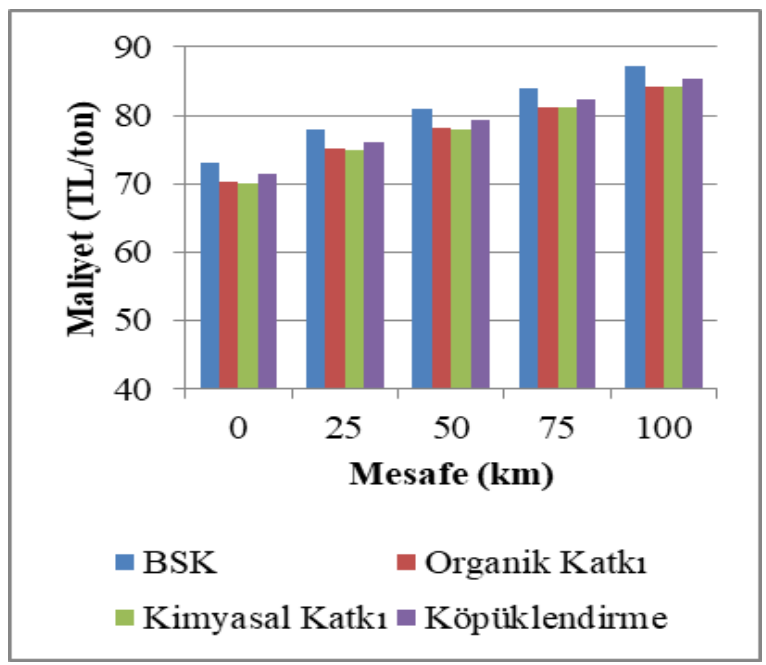

Şekil 2. 2012 yılı asfalt karışımları maliyeti

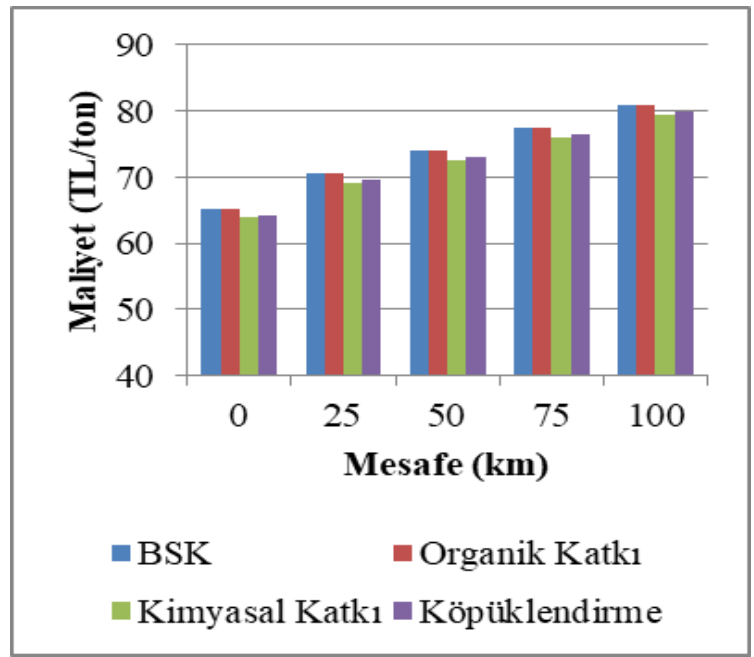

Şekil 4. 2014 yılı asfalt karışımları maliyeti

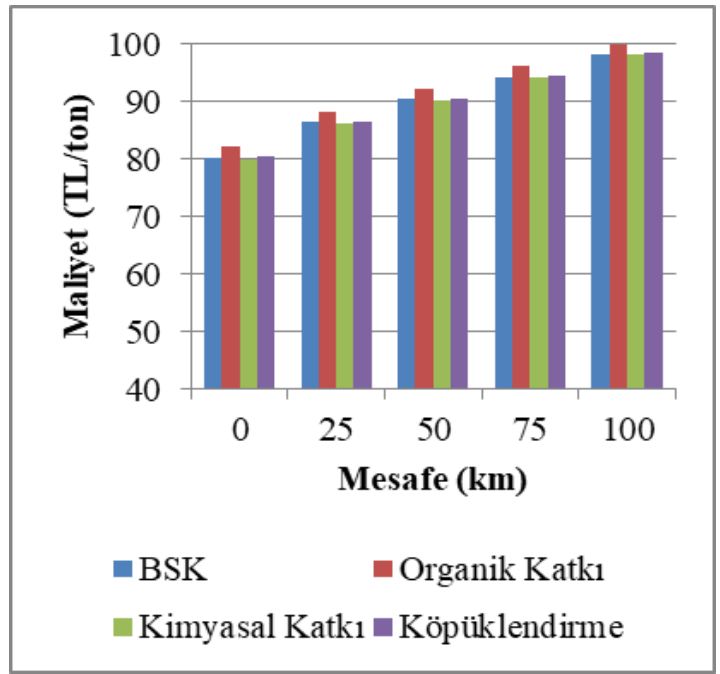

Şekil 6. 2016 yılı asfalt karışımları maliyeti

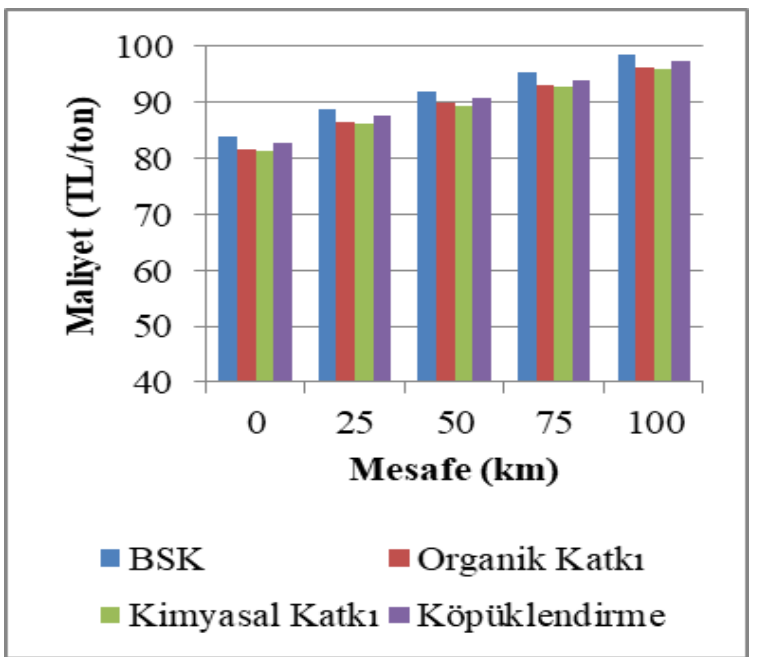

Şekil 3. 2013 yılı asfalt karışımları maliyeti

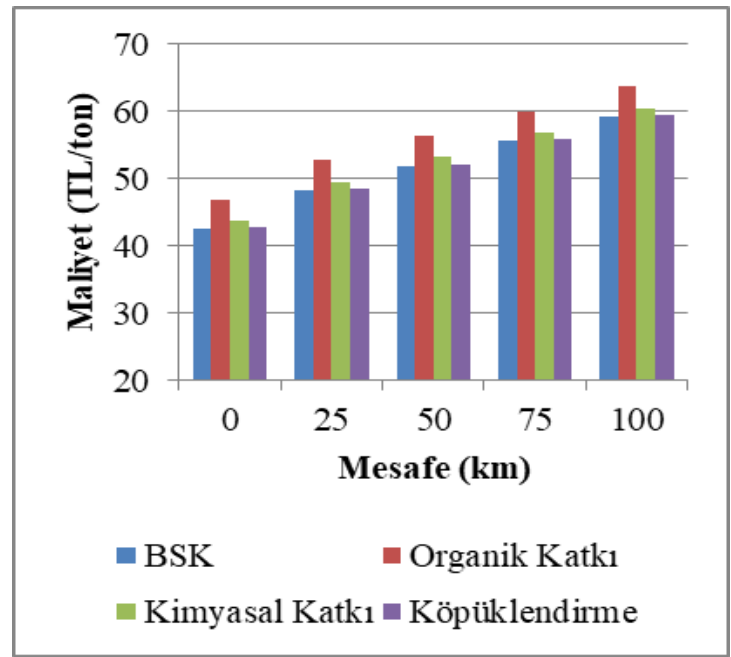

Şekil 5. 2015 yılı asfalt karışımları maliyeti

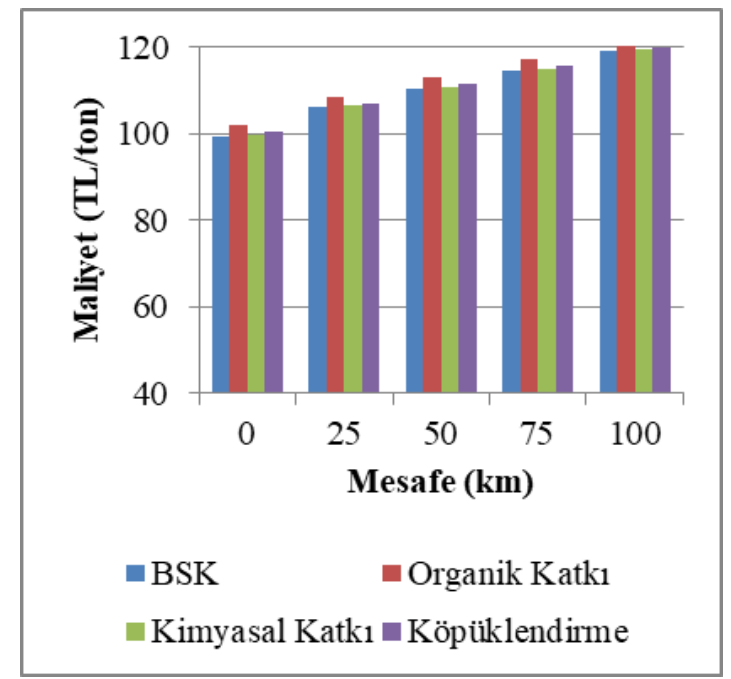

Şekil 7. 2017 yılı asfalt karışımları maliyeti 


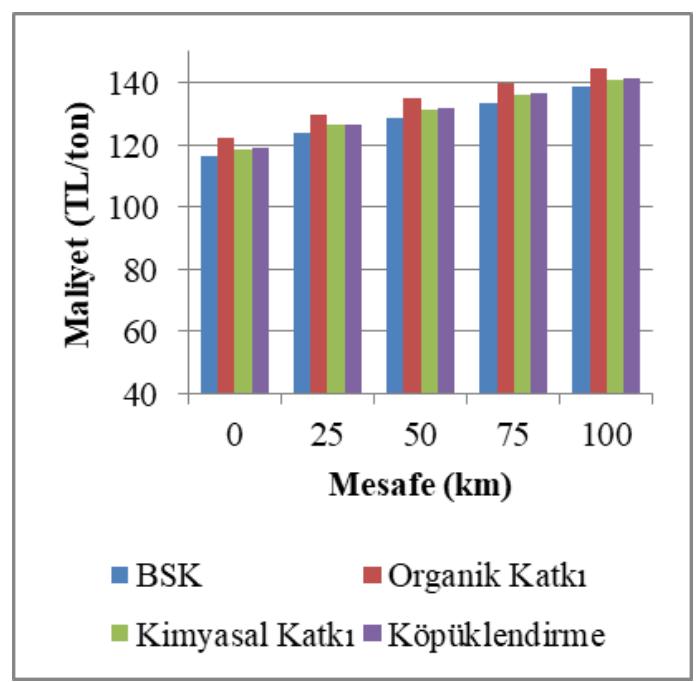

Şekil 8. 2018 yılı asfalt karışımları maliyeti

$\mathrm{Bu}$ nedenle 2012 y1lında herhangi bir katk1 türüyle elde edilen IKA'nın kullanılması, BSK kullanımına göre ekonomik avantaj sağlamaktadır En düşük maliyete sahip IKA ise kimyasal katkı kullanılarak üretilmiştir. $25 \mathrm{~km}$ taşıma mesafesine göre kimyasal katkılı IKA ile BSK'ya göre ton başına 2.97 TL tasarruf sağlanmaktadır.

2013 yılında IKA kullanımının BSK'ya göre ekonomik açıdan avantaj sağladığı açıkça görülmektedir (Şekil 3). Şekil 2 ve Şekil 3 karşılaştırıldığında; 2012 yılına göre asfalt karışımlarının ton başına üretim maliyetlerinin artmasına rağmen BSK ile IKA maliyetlerinin arasındaki maliyet farkının azaldığ görülmektedir.

Ancak IKA'ın tüm üretim yöntemlerine ait maliyetler BSK'ya göre farklı taşıma mesafelerine göre ekonomik olarak avantajlı haldedir. $25 \mathrm{~km}$ taşıma mesafesine göre kimyasal katkılı IKA ile BSK'ya göre ton başına 2.56 TL tasarruf sağlanmaktadır.

2014 yılına gelindiğinde ise petrol fiyatlarının düşmesi nedeniyle asfalt karışımı üretim maliyetinde de düşüş gözlemlenmektedir (Şekil 4). Ancak, 2013 y1lına göre petrolün varil fiyatının 97.69 TL'den 53.27 TL'ye düşmesine rağmen dolar kurundaki artış bitüm fiyatlarının aynı ölçüde düşmesini engellemiştir. Aynı zamanda kur artışıyla beraber, katkı maliyetinin artmasıyla birlikte IKA üretim maliyetindeki avantajın sinırlanmasının yanında 2012 ve 2013 yıllarına kıyasla IKA ve BSK arasındaki maliyet makasının daraldığı açıkça görülmektedir. 2014 y1lında kimyasal katk1lı IKA ile 1 ton asfalt karışımı üretiminde BSK'ya göre 1.27 TL tasarruf sağlanmaktadır.

2015 yılında asfalt karışımlarına ait üretim maliyetlerinin ciddi ölçüde düştüğü gözlenmektedir. Özellikle 2013 yılına göre bitüm fiyatlarındaki \%70.47'lik düşüş nedeniyle diğer yıllara göre asfalt karışımı üretiminde önemli tasarruf sağlandığı açıkça görülmektedir. Bitüm fiyatının düşmesi, asfalt karışımlarının maliyetinin ciddi oranda düşmesini sağlamıştır. Bunun yanında, döviz kurundaki yükselişle birlikte katk1 maliyetinin artmas1, IKA maliyetinin BSK'ya göre daha yüksek olmasına neden olmuştur. Şekil 5'te BSK'nın köpüklendirme teknolojisiyle üretilen IKA'ya göre 0.21TL'lik bir farkla daha ekonomik olduğu görülmektedir. Bu haliyle IKA teknolojisi, petrol fiyatları yüksek olduğunda, dolayısıyla bitüm fiyatlarının da yüksek olduğu dönemde, kullanımı avantajlı iken petrol fiyatları düşükken BSK 
kullanımı daha ekonomik hale gelmiştir (Köroğlu vd, 2015).

2016 yılına gelindiğinde ise $\mathrm{BSK}$ ve IKA maliyetlerinin 2013 yılına yakı olarak gerçekleştiği görülmektedir (Şekil 6). Gerek bitüm fiyatlarında, gerek döviz kurunda yaşanan artış 2015'e göre maliyetlerin artmasına neden olmuştur. Kimyasal katkılı IKA'ın BSK'dan ton başına 0.19 TL ekonomik avantaj sağladığı görülmektedir.

Şekil 7 ve Şekil 8'de de görüldüğü gibi 2017 ve 2018 yıllarında IKA, BSK karşısında ekonomik avantajını kaybetmiş ve BSK daha ekonomik hale gelmiştir. Bunun en büyük nedeni ise, döviz kurundaki artış nedeniyle, katkı maliyetinin toplam maliyete etkisi bitüm fiyatlarındaki artışın neden olduğu etkiden daha fazla olmasindan kaynaklanmaktadır. Farklı taşıma mesafelerine bağlı olarak her bir yıl için bağlayıcı maliyetinin toplam üretim maliyetindeki oran1 yüzdesel olarak Tablo 4'te gösterilmiştir. Buna göre; BSK üretiminde bağlayıcı maliyeti oranı, IKA'ya göre daha yüksektir. Bunun nedeni IKA üretiminde BSK'ya göre daha az oranda bitüm kullanılmasıdır. Petrol fiyatları yüksek olduğunda IKA'nın maliyet avantajı sağlamasının bir nedeni de daha az bitüm kullanılarak asfalt karışımı üretilebilmesidir. 2015 yılına bakıldığında, bitüm maliyetinin diğer yıllara göre ciddi oranda düşmesi, asfalt karışımlarının toplam maliyetinin de düşmesine neden olmuştur. Ayrıca taşıma mesafesi arttıkça toplam maliyet de arttığından bitümün üretim maliyetindeki oranı da düşüş göstermektedir.

Şekil 9'da y1llara göre BSK ve IKA maliyetinin eşitlendiği bitüm maliyetinin toplam maliyete oranı gösterilmiştir. Buna göre, bu oran eğrinin üzerinde olduğunda, IKA kullanımı ekonomik avantaj sunarken eğrinin altındaki oranlarda ise BSK kullanımı ekonomik bakımdan avantaj sağlamaktadır.

Tablo 4. BSK ve IKA maliyetinde bağlayıcının farklı taşıma mesafesine göre üretim maliyetindeki oranı

\begin{tabular}{l|lllll|lllll}
\hline & BSK & & & & & IKA & & & & \\
\hline Y1larKKm & 0 & 25 & 50 & 75 & 100 & 0 & 25 & 50 & 75 & 100 \\
\hline 2012 & $\% 72$ & $\% 68$ & $\% 65$ & $\% 63$ & $\% 61$ & $\% 70$ & $\% 65$ & $\% 63$ & $\% 61$ & $\% 58$ \\
2013 & $\% 74$ & $\% 70$ & $\% 67$ & $\% 65$ & $\% 63$ & $\% 71$ & $\% 67$ & $\% 64$ & $\% 62$ & $\% 60$ \\
2014 & $\% 63$ & $\% 58$ & $\% 56$ & $\% 53$ & $\% 51$ & $\% 60$ & $\% 55$ & $\% 53$ & $\% 50$ & $\% 48$ \\
2015 & $\% 43$ & $\% 38$ & $\% 35$ & $\% 33$ & $\% 31$ & $\% 41$ & $\% 36$ & $\% 34$ & $\% 32$ & $\% 30$ \\
2016 & $\% 66$ & $\% 61$ & $\% 58$ & $\% 56$ & $\% 54$ & $\% 65$ & $\% 60$ & $\% 57$ & $\% 55$ & $\% 53$ \\
2017 & $\% 69$ & $\% 65$ & $\% 62$ & $\% 60$ & $\% 58$ & $\% 68$ & $\% 63$ & $\% 61$ & $\% 59$ & $\% 56$ \\
2018 & $\% 70$ & $\% 66$ & $\% 64$ & $\% 61$ & $\% 59$ & $\% 67$ & $\% 63$ & $\% 61$ & $\% 59$ & $\% 57$ \\
\hline
\end{tabular}




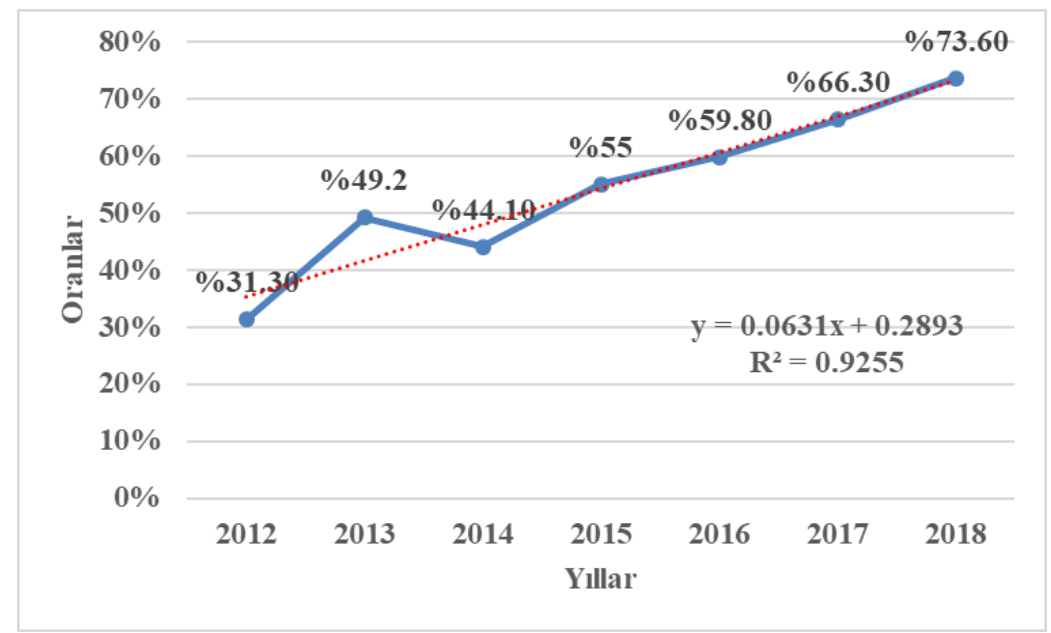

Şekil 9. BSK ve IKA'nın maliyetlerinin eşitlendiği bitüm maliyet oranları

Ayrıca, 2014 yılı hariç tutulursa, bitümün toplam maliyet üzerindeki etkisi y1llara göre önemli şekilde artış göstermiştir. 2012 yılından 2018 yılına gelindiğinde asfalt üretimi için gereken diğer kalemlerde çok ciddi bir artış olmamasına rağmen (KGM, 2018) bitüm fiyatlarında \%55 oranında artış meydana gelmiştir (Tablo 2). $\mathrm{Bu}$ artış ise BSK maliyetinin \%59 oranında yükselmesine neden olan en önemli etken faktör olarak öne çıkmaktadır. 2013 yılında ise diğer yıllardan daha büyük oranda bir artış meydana geldiği görülmektedir. Bunun sebebi ise bitüm fiyatlarının artış göstermesiyle birlikte, katkı kullanılmasından dolayı IKA maliyetini etkileyen avro kur değerindeki artışın bitümdeki artış oranından düşük kalmasıdır. Başka bir açıdan, 2014 yılında IKA kullanımının BSK'ya göre ekonomik avantaj sağlamasının nedeni de bu şekilde açıklanabilmektedir. Şekil 9 genel olarak incelenirken, bitüm fiyatlarının yanında avro kurunun da değerlendirilmesi gereklidir. Çünkü elde edilen eğim çizgisi, BSK ve IKA'nın maliyetlerinin eşitlendiği bitüm oranlarını gösterdiğinden dolayı, IKA maliyetini etkileyen parametrelerden olan katk1 maliyetini de yansitmaktadir.
$\mathrm{Bu}$ nedenle şekildeki eğim çizgisi tek başına bitüm fiyatlarına endeksli değildir. Yıllar içinde bitüm fiyatlarının artmasının yanında avronun da artış göstermesi nedeniyle, 2018 yılında BSK ve IKA'yı dengeleyen maliyet oranı \%73.60'a kadar yükselmiştir. Şekil 9'daki eğri, doğrusal şekilde ifade edilmek istenirse, $\mathrm{y}=0.0631 \mathrm{x}+0.2893$ denklemi ve $\mathrm{R}^{2}=0.9255$ elde edilmektedir.

2012 ile 2018 yılları arasında, bağlayıcının IKA ve BSK'nın toplam üretim maliyetindeki payının değişimini gösteren grafikler sırasıyla her bir yıl ve $25 \mathrm{~km}$ taşıma mesafesi için Şekil 10, Şekil 11, Şekil 12, Şekil 13, Şekil 14, Şekil 15 ve Şekil 16 'da gösterilmiştir. Bu grafikler elde edilirken Tablo 4'den yararlanılmıştır. Buna göre, asfalt karışımlarının maliyetlerinde en büyük belirleyici faktör bitüm maliyeti olmuştur. Bu nedenle 2012 yılında IKA maliyeti, BSK'ya göre daha düşük olurken 2015 yılında bitüm fiyatlarındaki değişim ve döviz kurundaki artışın da etkisiyle IKA maliyeti BSK'dan daha yüksek olmaktadır. 2018 yılına gelindiğinde ise BSK'nın IKA karşısında maliyet avantajı devam etmiştir. Diğer maliyetlerde y1llara göre önemli değişiklikler olmamıştır. 2012, 2013, 2014 ve 2016 yıllarında IKA BSK'ya göre ton başına 2.97 TL ile 0.19 TL. 


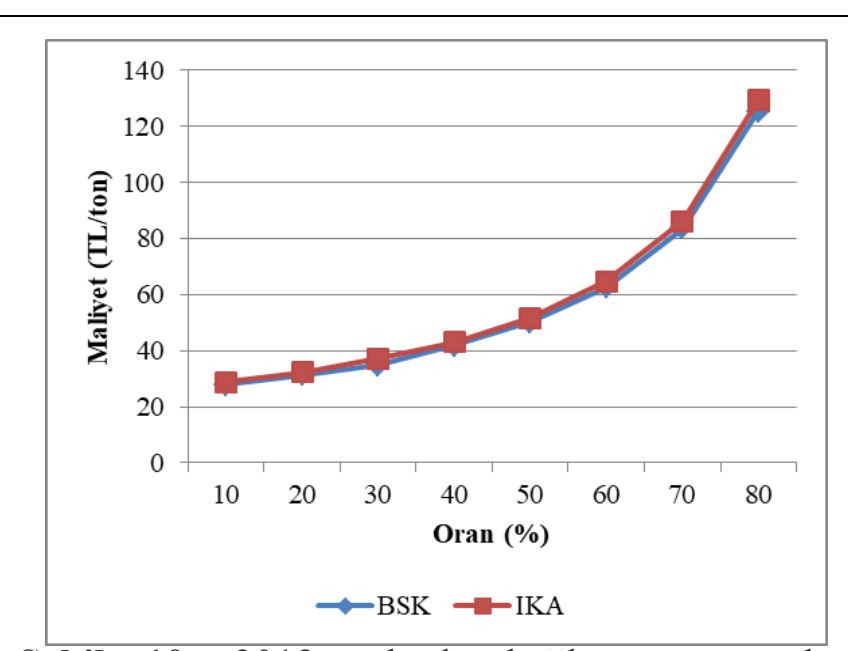

Şekil 10. 2012 yılında bağlayıcının toplam üretimdeki pay1

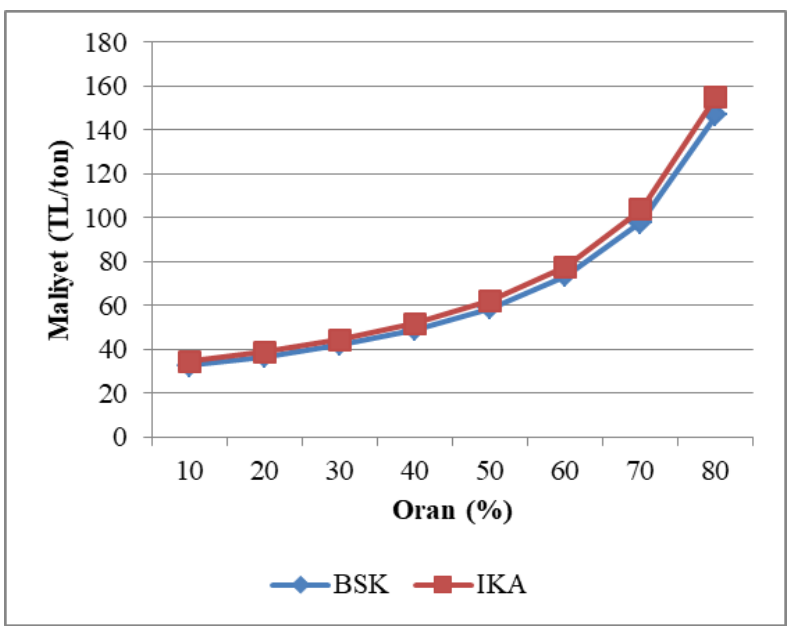

Şekil 12. 2014 yılında bağlayıcının toplam üretimdeki payı

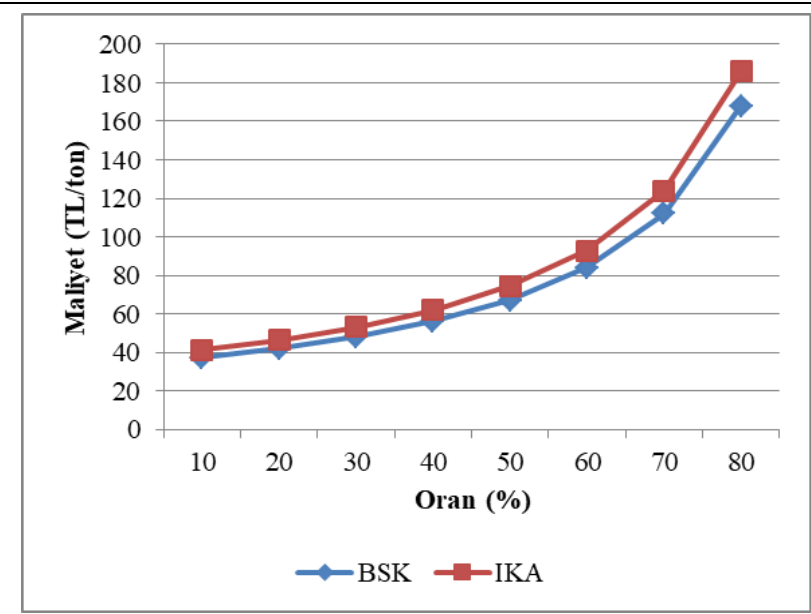

Şekil 14. 2016 yılında bağlayıcının toplam üretimdeki payı

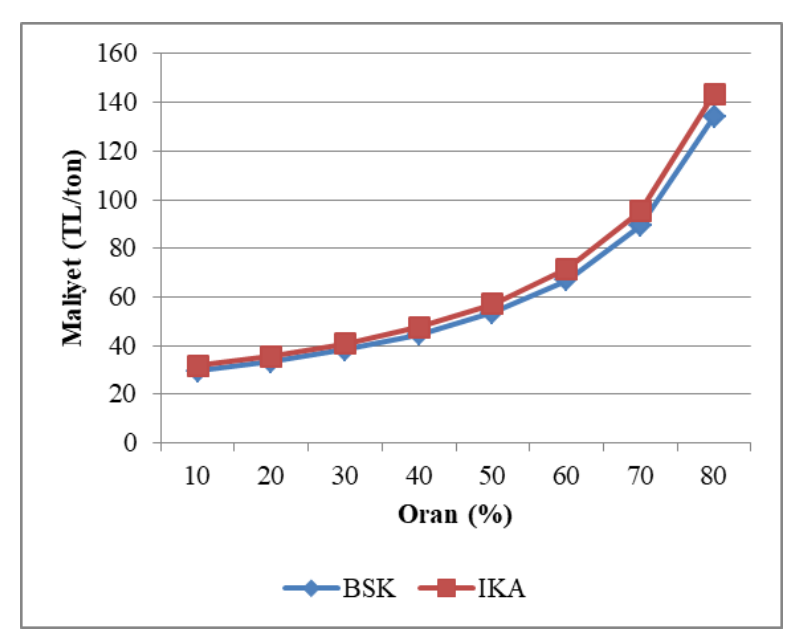

Şekil 11. 2013 yılında bağlayıcının toplam üretimdeki payı

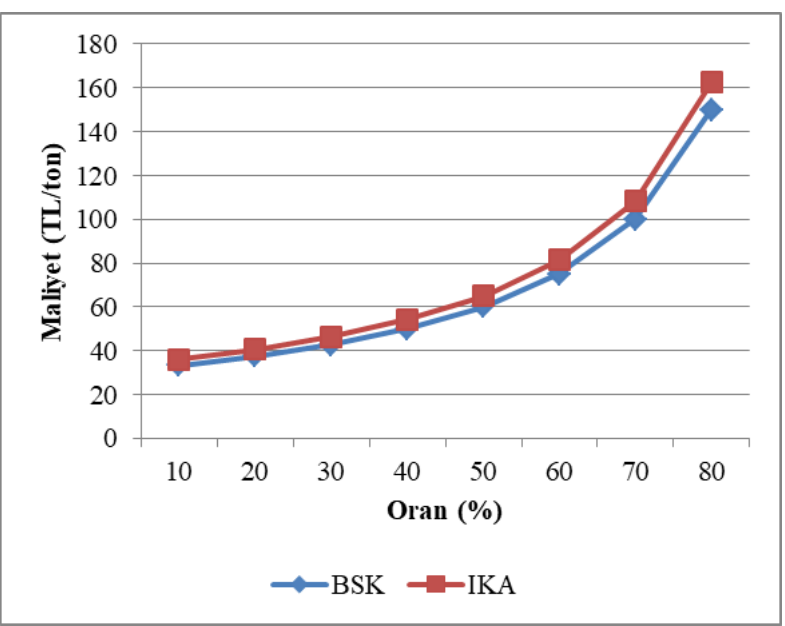

Şekil 13. 2015 yılında bağlayıcının toplam üretimdeki payı

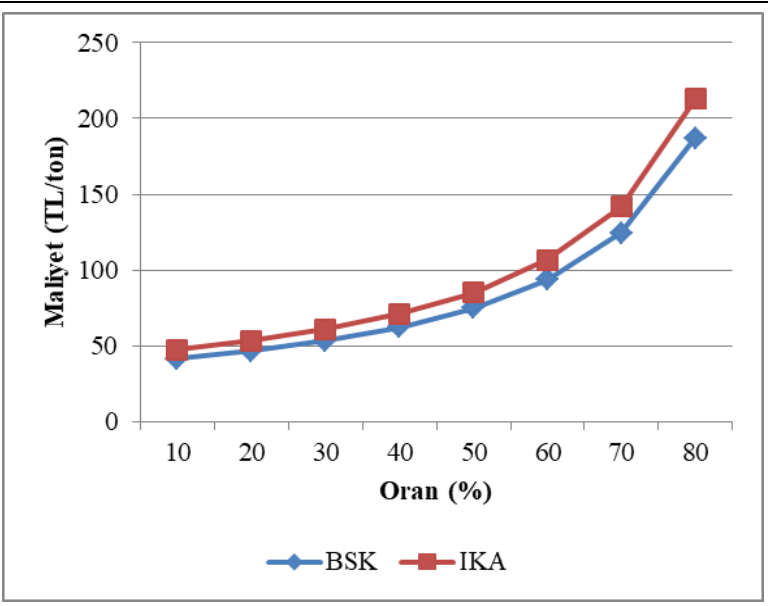

Şekil 15. 2017 yılında bağlayıcının toplam üretimdeki payı 


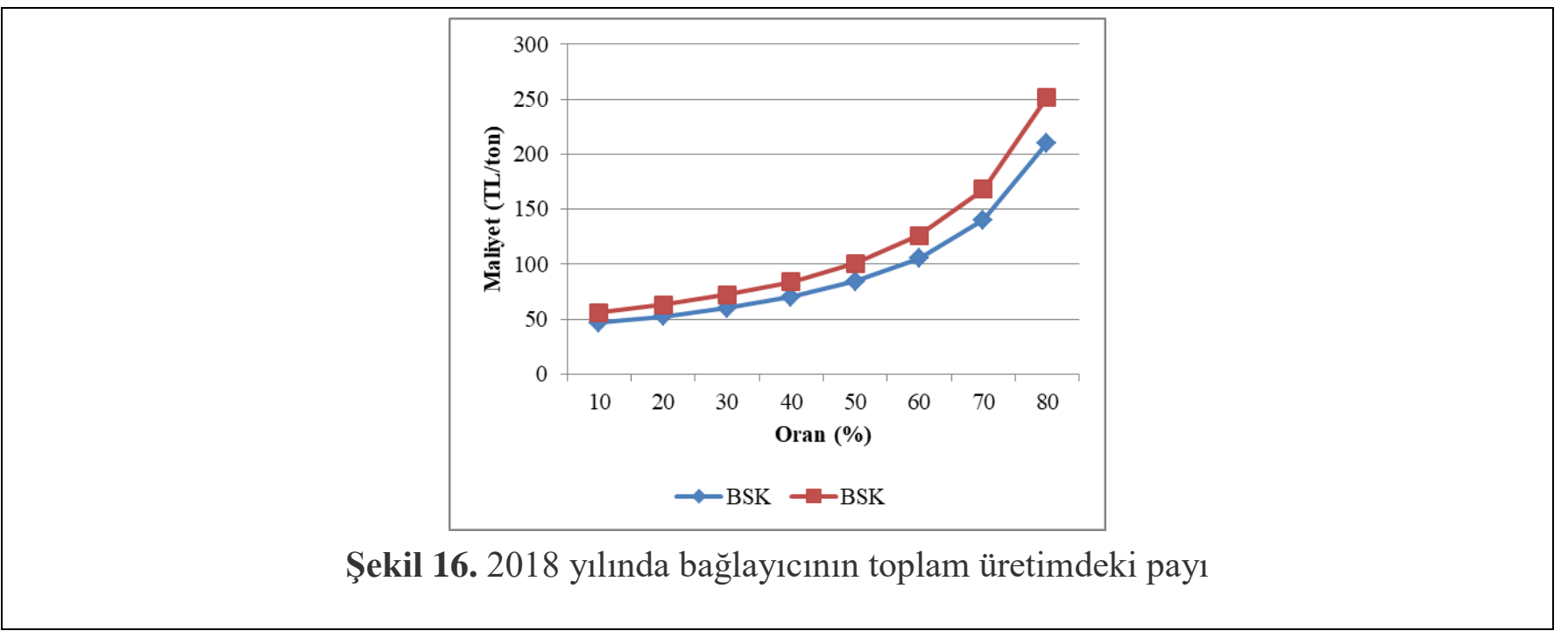

arasında maliyet avantajı sağlarken; 2015, 2017 ve 2018 yıllarında BSK IKA'ya göre ton başına 2.5 TL ile 1.25 TL arasında maliyet avantaj1 sunmaktadır. Bu maliyet farkının ana sebebi ise üretim aşamalarında farklı oranlarda bitüm ve farklı tipte katkı malzemesi kullanılması ve yıllara göre döviz kurlarının değişkenlik göstermesinden kaynaklandığı görülmektedir. Bağlayıcının toplam üretimdeki payının arttırılmasıyla, BSK ile IKA arasındaki ilişkiyi ifade eden grafiklerdeki eğim çizgileri arasındaki fark belirgin şekilde farklılaşmıştır.

\section{2. Çevresel Karşılaştırma}

Çevreye salınan emisyon gazlarının insan sağlığına çok çeşitli etkileri vardır. Şüphesiz ki asfalt karışımlarının üretilmesinde ekonomik olarak bir maliyet olduğu gibi insan sağlığına etkisi ve doğaya verdiği zararlar nedeniyle de bir maliyetin ortaya çıkması kaçınılmazdır. 1 ton BSK üretimi sırasında bitümün üretilmesi ve plente taşınması, agreganın üretilmesi ve plente taşınması, plentte üretim işlemi, üretilen asfalt karışımın sahaya taşınması ve serilmesi sırasında açığa çıkan emisyon gazlarının $\left(\mathrm{NO}_{\mathrm{x}}, \mathrm{CO}_{2}, \mathrm{CO}\right.$, $\mathrm{HC}$ gazları ile toz ve uçucu parçacıklar) $1 \mathrm{~kg}$ maliyeti (Hadi et al., 2008) ve köpüklendirme teknolojisi kullanılarak üretilen IKA kullanımının sağladığı çevresel maliyetteki azalma miktarlarının parasal karşılığı Tablo 5'te gösterilmiştir. $\mathrm{Bu}$ maliyetlerin hesaplanmasında emisyon gazlarının insan sağlığına etkileri ve neden olduğu sağlik problemlerinin tedavi ve iş gücü kaybı bakımından maliyeti etkili olmuştur (Hadi et al., 2008). Yapılan farklı çalışmalar incelendiğinde IKA kullanımı sayesinde emisyon gazı salımında farklı azalma oranları elde edilmiştir (D’Angelo, 2008). Bu çalışmada literatür incelemesi sonucunda, IKA'nın sağladığı azalma oranları arasından en düşük azalmanın elde edildiği oranlar dikkate alınmıştır (Hassan, 2010). İlgili y1llarda elde edilen azalma maliyetleri, Tablo 1'deki kur değerlerine göre hesaplanmıştır.

Tablo 5'e göre, 2012 yılında toplam çevresel maliyetteki azalma miktarı 4.79 TL/ton iken, yıldan yıla sağladığı avantaj artarak 2018 yılında $14.14 \mathrm{TL} /$ tona ulaşmıştır. Görüldüğü gibi, 2018 yılında 2012 y1lına göre çevresel maliyet avantaj1 bakımından BSK'ya göre 2.95 kat gibi çok ciddi bir oranda artış kaydedilmiştir. Bu artışın nedeni tamamen dolar kurunda yaşanan yükselmeden dolayidır. 
Tablo 5. 1 ton BSK üretiminde açığa çıkan emisyon gazı miktarları ve IKA ile sağlanan azalmanın parasal karşılı̆̆1

\begin{tabular}{|c|c|c|c|c|c|c|c|c|c|c|c|}
\hline \multirow{2}{*}{ 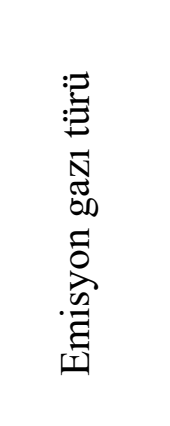 } & \multirow{2}{*}{ 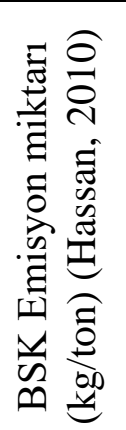 } & \multirow{2}{*}{ 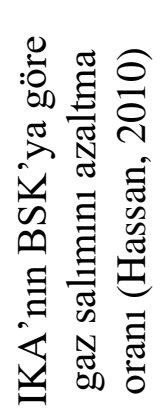 } & \multirow{2}{*}{ 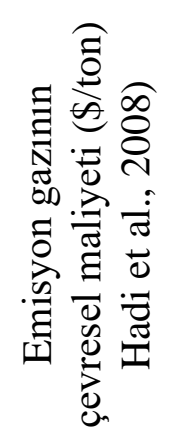 } & \multirow{2}{*}{ 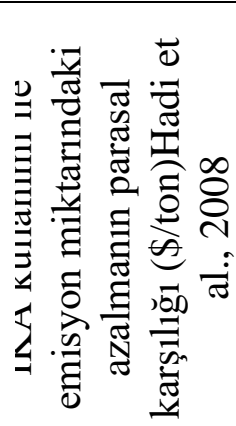 } & \multicolumn{7}{|c|}{$\begin{array}{l}\text { Yillara göre IKA kullanımının sağladiğı emisyon } \\
\text { azalmasının parasal karşılığı (TL/ton) }\end{array}$} \\
\hline & & & & & $\stackrel{\sim}{\stackrel{2}{\sigma}}$ & $\stackrel{m}{\stackrel{n}{i}}$ & 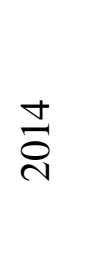 & $\frac{n}{2}$ & $\stackrel{0}{\stackrel{0}{i}}$ & 호 & $\frac{\infty}{i}$ \\
\hline $\mathrm{NO}_{\mathrm{x}}$ & 0.71 & $\% 60-70$ & 3731 & 1.59 & 2.86 & 3.42 & 3.58 & 4.64 & 5.53 & 6.05 & 8.44 \\
\hline $\mathrm{CO}_{2}$ & 32 & $\% 15-40$ & 3.56 & 0.017 & 0.03 & 0.04 & 0.04 & 0.05 & 0.06 & 0.06 & 0.09 \\
\hline $\mathrm{CO}$ & 2.6 & $\% 10-30$ & 3889 & 1.011 & 1.82 & 2.17 & 2.27 & 2.95 & 3.52 & 3.85 & 5.37 \\
\hline $\mathrm{HC}$ & 0.27 & - & 1774 & - & - & - & - & - & & & \\
\hline $\begin{array}{c}\text { Toz ve } \\
\text { uçucu } \\
\text { maddeler }\end{array}$ & 0.016 & $\% 25-55$ & 11066 & 0.045 & 0.08 & 0.10 & 0.10 & 0.13 & 0.16 & 0.17 & 0.24 \\
\hline & & & Toplam & 2.663 & 4.79 & 5.72 & 5.99 & 7.77 & 9.26 & 10.14 & 14.14 \\
\hline
\end{tabular}


Çünkü çevresel maliyet için, 1 ton BSK üretimi sırasında açığa çıkan emisyon gazı sabit üründür (Hadi et al., 2008). Daha önce hesaplanan BSK ve IKA'ya ait ekonomik maliyetler dikkate alındığında, IKA kullanımının çevresel faydasının parasal karşılığı, ekonomik faydasına kıyasla çok daha baskın olduğu açık şekilde ortaya çıkmaktadır (Hassan, 2010). Bu nedenle, IKA ve BSK kullanım tercihi hususunda, çevresel faktörler ekonomik etkenlere açık şekilde baskın çıkmaktadır (Random et al., 2015).

\section{Sonuçlar}

Petrol fiyatlarının yüksek olduğu 2012 y1lında 38.3 milyon ton BSK kullanılmıştır. Yapılan hesaplamalar sonucunda kimyasal katkı kullanılarak üretilen IKA ile ton başına 2.97 TL tasarruf sağlanmaktadır. Bu durumda 2012 y1lında IKA teknolojisinin kullanılması halinde ülkemize 113.75 Milyon TL fayda elde edilecektir. Aynı şekilde 2013 y1lında IKA ile $2.56 \mathrm{TL} /$ ton tasarruf edilirken toplamda kullanılan 46.2 milyon ton BSK yerine IKA kullanılması durumunda ise 118.27 Milyon TL tasarruf sağlanmaktadır. 2015 yılında ise petrolün varil fiyatlarında yaşanan ciddi düşüşle birlikte asfalt karışımlarının üretim maliyetinde ciddi oranda düşüş gözlenmiştir. Bu durum, 2015 yılı için BSK kullanımını IKA'ya göre daha ekonomik hale getirmiştir.

Bağlayıcı maliyetinin toplam asfalt karışım maliyetindeki oranı 2012 y1lı için \%31.3 2013 y1lı için \%50 2014 y1lı için \%45.1, 2015 y1lı için \%46.1, 2016 y1lı için \%59.8, 2017 yılı için \%66.3 ve 2018 y1lı için \%73.6 değerinden fazla olması durumunda IKA kullanımı BSK kullanımına nazaran daha ekonomik hale gelmektedir. $\mathrm{Bu}$ oran taşıma mesafesine bağlı olarak azalmaktadır.
Kimyasal katk1lı IKA'ın maliyeti, hemen hemen tüm y1llarda en düşük maliyetin elde edilmesini sağlarken; organik katkılı IKA'nın ise en yüksek maliyetle üretim sağladığ 1 görülmektedir.

Y1llara göre gerek döviz kurunda yaşanan artış gerek bitüm fiyatlarındaki değişim nedeniyle, farklı yıllarda IKA veya BSK kullanımını daha avantajlı hale gelmiştir. Ekonomik açıdan en avantajlı asfalt karışımını belirlemek için bitüm ve avro kurunun toplam maliyete etkisi birlikte değerlendirilmelidir. Yıldan yıla asfalt karışımlarının maliyetinin -2014 ve 2015 yılı hariç- arttığ1 görülmektedir. Bu maliyetin içerisinde bitüm maliyetiyle birlikte avronun etkisinin de her geçen yıl arttığı göz önüne alındığında, IKA ülkemiz için ekonomik açıdan avantaj sağlamaktan giderek uzaklaşmaktadır.

Taşıma mesafesi arttıkça asfalt karışımlarının maliyetlerinde de artış meydana gelmiştir. Ancak, taşıma mesafesinin artmasıyla her iki karışımın maliyetleri eşit miktarda artmasına rağmen, BSK'nın maliyetinin IKA'nın maliyetinden yüksek olması nedeniyle, uzun mesafe taşımada bitümün toplam maliyet içerisindeki payı BSK'da daha yüksek olmaktadır.

Farklı yıllar itibariyle çevresel etkileri dikkate aldığımızda petrol fiyatının en yüksek olduğu 2013 yılı için çevresel etkilerdeki faydası ton başına 5.72 TL iken 2015 y1lı için bu rakam 7.77 TL'dir. 2018 yılında ise IKA, BSK'ya göre ekonomik açıdan avantajı olmamasına rağmen ton başına 14.14 TL gibi çok ciddi bir fayda sağlamaktadır. Yani çevresel etkilerin dikkate alınması durumunda petrol fiyatı ne kadar olursa olsun IKA'nın maliyeti BSK'ya nazaran daha düşük olmaktadır. IKA'nın 
çevresel faydası için yapılan çalışmalara göre 2015 y1lında üretilen 30.9 milyon ton BSK'nın IKA ile üretilmesi durumunda 240 Milyon TL çevre katkısı sağlamak mümkün olmaktadır. Bu rakamların hesaplanmasında; emisyon gazının insan ve çevre sağlığı üzerine etkileri etkili olmuştur.

$\mathrm{Bu}$ çalışmada ortaya konan ekonomik ve çevresel maliyet analizi karşılaştırması, IKA teknolojisinin yeni olması ve üzerinde yeterince çalışma yapılmamış bir konuya değinmesi yönüyle özgünlük ifade etmektedir. Sonuç olarak IKA kullanımının en büyük katkısının çevresel faydası olduğu göz önünde tutulmalıdır. IKA'nın kullanılmasına karar verilirken, üretim maliyetinin yanında çevre dostu bir karışım olan IKA'nın çevresel açıdan sağladığı faydaların da dikkate alınmasının gerekliliğ $i$ ortaya çıkmaktadır. $\mathrm{Bu}$ sebeple sonraki yıllarda yapılan çalışmalarla daha da genişletilerek IKA tüm yönleriyle incelenmelidir.

\section{Kaynaklar}

Arega, Z., Bhasin, A., 2012. "Interim Report: Binder Rheology and Performance in Warm Mix Asphalt", Texas Transportation Institute, Texas, USA, Retort No. 0-6591.

Asfalt Mütahitleri Derneği-ASMÜD, 2019. "Türkiye'de Rakamlarla Asfalt", http://www.asmud.org.tr/asfalt.php?sayfa=25 , Son erişim tarihi: 01.03.2019.

Bueche N., 2009. "Warm Asphalt Bituminous Mixtures with Regards to Energy, Emissions and Performance Young Researchers Seminar" Torino, Italy, (YRS) LAVOC-CONF-2010-002, 2009.

Chowdhury, A., Button, J. W., 2008. "A review of warm mix asphalt", Texas: TexasTransportation Institute, The Texas A\&M University.
Croteau, J.M., Tessier, B., 2008. "Warm Mix Asphalt Paving Technologies: a Road Builder's Perspective", In Annual Conference of the Transportation Association of Canada, Toronto, p120.

D’Angelo, J., Harm, E., Bartoszek, J., Baumgardner, G., Corrigan, M., Cowsert at al., 2008. "Warm-Mix asphalt: European practise". Federal Highway Administration Office of International Programs. Washington DC, USA, No. FHWA-PL-08007.

Dokandari, P., 2012. Effects of Warm Mix Asphalt Additives on Aging Characteristics of Bituminous Mixtures. PhD Thesis, Dokuz Eylul University, İzmir, 50-55.

Estakhri, C., Button, J., Alvarez, E., 2010. "Field and laboratory investigation of warm mix asphalt in Texas". Texas: Texas Transportation Institute, The Texas A\&M University.

Hadi, M., Xiao, Y., Ozen, H., Alvarez, P., 2008. "Evaluation Tools to Support ITS Planning Process: Development of a Sketch Planning Tool in FSUTMS/Cube Environment", Florida Department of Transportation, Florida, USA.

Hassan, M., 2010. "Evaluation of the Environmental and Economic Impacts of Warm-Mix Asphalt Using Life-Cycle Assessment", International Journal of Construction Education and Research. 6(3), 238-250.

Hurley, G.C., Prowell, B.D., 2006 "Evaluation of potential process for use in warm mix asphalt". Journal of the Association of Asphalt Paving Technologists, 75, 41-90.

Investing Yatırım Hizmetleri, 2019. "Döviz kurları", www.tr.investing.com, Son erişim tarihi: 01.03.2019.

Kanitpong, K., Nam, K., Martono, W., Bahia, H., 2008. "Evaluation of a warm mix 
asphalt additive", Proceedings of the Institution of Civil Engineers-Construction Materials, 161(1), 1-8.

Karayolları Genel Müdürlüğü (KGM), 2018. "Yol, Köprü, Tünel, Bitümlü Kaplamalar, Bakım Ve Trafik İşlerine Ait Birim Fiyat Listesi”, Ankara, Türkiye.

Kaya, D., 2014. "Ilık Karışım Asfaltların Mekanik Özelliklerinin İncelenmesi”, Yüksek Lisans Tezi, Dokuz Eylül Üniversitesi, Fen Bilimleri Enstitüsü, İzmir.

Köroğlu HJ, Demir B, Öz B, Temel S, Ateş M, Sağlık A. "Ilık Karışım Asfalt Katkıları Üretim Teknolojilerinin Geliştirilmesi”. Yol Teknolojileri Dergisi, 6(32), 46-78, 2015.

Kristjansdottir, O., 2006. "Warm Mix Asphalt for Cold Weather Paving," University of Washington, Seattle, Washington, Report No. WA-RD 650.1,

Kristjansdottir, O., Muench, S.T., Michael, L., Burke, G., 2007. "Assessing potential for warm-mix asphalt technology adoption". Transportation Research Record, 2040 (1), 91-99.

Mansourian, A., Razmi, A., Razavi, M., 2016. "Evaluation of fracture resistance of warm mix asphalt containing jute fibers", Construction and Building Materials, 117:37-46.

Maurer, D.A., Malasheskie, G.J., 1989. "Field performance of fabrics and fibers to retard reflective cracking", Geotextile and Geomembranes, 8(3):239-267.

O'Sullivan, K., Wall, P., 2009. "The effect of warm mix asphalt additives on recycled asphalt pavement". Worcester, Massachusetts: Worcester Polytechnic Institute.

Oylumluoğlu, J., 2012. "The Utilization of Recycled Asphalt Concrete With Warm Mix Asphalt, Doktora Tezi, Dokuz Eylül Üniversitesi, Fen Bilimleri Enstitüsü, İzmir
Pekin, M.A., 2006. "Ulaștırma Sektöründen Kaynaklanan Sera Gazı Emisyonları”, Yüksek Lisans Tezi, İstanbul Teknik Üniversitesi, İstanbul.

Rondon, H.A., Hernández, J.A., Reyes, F.A., 2015. "A review of warm mix asphalt technology: technical, economical and environmental aspects". Ingenieria Investigation, 35(3), 5-18.

Rubio, M.C., Martinez, G., Baena, L., Moreno, F., 2012. "Warm mix asphalt: an Overview", Journal of Cleaner Production, 24, 76-84.

TUBITAK MAM ve KGM, 2014. "Ilık Karışım Asfalt Katkıları Üretim Teknolojilerinin Geliştirilmesi Raporu", Gebze

Tüpraş, 2019. "Güncel bitüm fiyatları”, https://www.tupras.com.tr/bitum-fiyatlariguncel”, Son erişim tarihi: 01.03.2019.

Türkiye Cumhuriyeti Merkez Bankası, 2019. "Gösterge Niteliğinde Merkez Bankası Kurları"

https://www.tcmb.gov.tr/wps/wcm/connect/tr /tcmb+tr/main+menu/istatistikler/doviz+kurl ari/gosterge+niteligindeki+merkez+bankasi+ kurlarii, Son erişim tarihi: 01.03.2019. 